\title{
Indigenous Policy and Mutual Obligation: Shared or Shifting Responsibility Agreements?
}

Ruth McCausland and Marc Levy

\begin{abstract}
Shared Responsibility Agreements (SRAs) are a key instrument of the Federal Government's new arrangements for the administration of Indigenous affairs. SRAs, described by the Government as a form of 'mutual obligation', require Indigenous communities to commit to behavioural changes or other actions in order to access 'discretionary' government funding for infrastructure or services. There are significant political, moral and practical issues raised by SRAs. In this paper we contend that despite the language of mutuality, flexibility and choice that accompanies SRAs, the approach appears more aptly associated with 'divide and conquer' tactics and a subtle shifting of responsibility for problems from governments to Indigenous communities themselves. In this paper we explore the concepts of mutual obligation and reciprocity, the structural biases that favour the state and its agencies over Indigenous communities in the SRA negotiation process, and issues of citizenship entitlements and accountability that are raised. Finally, acknowledging that SRAs can be a means for Indigenous communities to access greatly needed funding, we suggest various strategies and measures that could be taken up to make the SRA framework more equitable and effective.
\end{abstract}

Keywords: Indigenous policy, Mutual obligation, Shared Responsibility Agreements 


\section{Introduction}

In April 2004, the Australian Government announced the abolition of the Aboriginal and Torres Strait Islander Commission (ATSIC) and the introduction of its 'new mainstreaming' approach to the administration of Indigenous affairs (Howard, 2004a). Shared Responsibility Agreements (SRAs) have been presented as a key instrument of the Government's new approach, and described by the former Minister for Immigration, Multicultural and Indigenous Affairs as marking the start of a 'quiet revolution' in Indigenous affairs (Vanstone, 2005 cited in Peatling, 2005). An extension of the Government's 'mutual obligation' philosophy, SRAs involve governments pledging to fund infrastructure or services in exchange for Indigenous communities committing to measures in return, generally conforming to broader social or behavioural expectations. In this paper we set out the background to SRAs, some detail of their progress to date, a series of issues raised by the SRA and mutual obligation approach, and a possible way forward to deal with some of the criticisms of the SRA framework.

\section{The SRA Context}

The Government's new approach in Indigenous policy has been presented as being premised on the principles of collaboration, with mainstream government departments working in a co-ordinated manner with Indigenous communities; as focused on regional need; as characterised by flexibility in working with Indigenous communities; as emphasising accountability using socio-economic indicators to test the effectiveness with which 'practical reconciliation' is being delivered; and as stressing the importance of shared leadership by governments (Shergold, 2004). The Government describes SRAs as agreements that:

...spell out what all partners - communities, governments and others - will contribute to bring about long-term changes which will achieve better outcomes for Indigenous communities' (OIPC, 2006).

SRAs are 'good faith agreements' made in 'the spirit of non-legal partnership and shared responsibility' (Brough cited in Calma, 2006a: 89). The Government states that SRAs involve only 'discretionary' funding and will not apply extra conditions to Indigenous people's access to benefits or services available to all Australians (OIPC, 2006).

The first SRAs were negotiated as part of the Council of Australian Government (COAG) trial sites in various regions around the country (COAG, 2002). These trial sites sought to explore what change could be effected in Indigenous communities with intensive government co-operation and resourcing. These early SRAs were broad statements of commitment by the communities and Commonwealth and State/Territory governments working in those trial sites, identifying strategic areas for action. The COAG trials have not been comprehensively evaluated. Nevertheless, the Government has stated that the COAG trials form the basis for their new arrangements. In particular, the Government embraced the language and concept of SRAs, although has transformed them into single-issue agreements with specific amounts of funding tied to them. SRAs are administered through the Indigenous Co-ordination Centres that replaced the ATSIC Regional Offices, now made up of staff from various Commonwealth Government agencies. 
To date (at 30 June 2006), 121 SRAs have been announced by the Minister between various Indigenous groups and organisations, and different agencies of the Commonwealth Government (OIPC, 2006). Relevant State or Territory Government agencies are also a party to a significant number of those SRAs; other parties include mining companies, corporations and local governments (Calma, 2006a: 35). The Commonwealth Government states that it has committed \$27 million of funding for SRA activities (OIPC, 2006). Those SRAs have been described as including initiatives addressing nutrition, community safety, business support, skills development and a range of other community needs, with communities in return making commitments such as improving school attendance, controlling substance misuse and being involved in youth recreation activities (OIPC, 2006).

\section{The Mulan SRA - patronising and coercive, or a question of culture?}

The response to these SRAs has been mixed, invoking fierce ideological debate regarding what constitutes sound and effective Indigenous policy. In particular, a draft SRA made public by the Federal Opposition in December 2004 in the remote Aboriginal community of Mulan in Western Australia polarised commentators. The Mulan SRA stated that in return for the community committing to certain hygiene measures such as washing children's faces and emptying rubbish bins in an attempt to address endemic health problems, the Federal Government would contribute funds for petrol bowsers in the community. As part of the agreement, the WA Government also undertook to monitor and review the adequacy of health services in the area, where trachoma rates have been described as the worst in the world. The draft SRA was presented by the Government as 'an example of how we want to work in all the communities' (Vanstone, 2004 cited in Donald, 2004). The Federal Opposition described it as 'patronising and coercive' (Carr 2004, cited in Hall, 2004).

While various Indigenous leaders criticised the Mulan SRA as racially discriminatory (Dodson, 2004 cited in Kelly, 2004) and as offensively implying that 'people need to sit up and beg' (Martin, 2004), then Minister Vanstone responded:

A community gets what it wants - a petrol bowser ... and the kids get better health outcomes. Who could complain about that? (Vanstone, 2004 cited in Donald, 2004).

Members of the Mulan community wrote a letter to the editor of The Age in support of the SRA:

We want to be recognised as Australians - not separated as blacks and whites. We want to be equal - and this means in our health too (Doonday et al, 2005).

In response to the debate, the Prime Minister stated:

...it is not just a question of money, because a lot more money has been put into Aboriginal health. It is a question of culture. It is a question of practice. It is a question of attitude. It is a question of community responsibility (Howard, 2004b). 
On 28 December 2004, the results of a Newspoll survey (2004) regarding SRAs reported in the media indicated that more than two-thirds of Australians surveyed were supportive of such agreements (respondents were informed of details of the Mulan agreement then asked whether they agreed with such agreements between Aboriginal communities and governments).

After revelations that the Mulan community had actually initiated the face-washing program 18 months earlier (Pennells, 2004), Australians for Native Title and Reconciliation National Director, David Cooper, stated that SRAs were:

...a massive con. They are not proper evidence-based agreements. ... work that is essentially ongoing is being rebadged as shared responsibility. It implies to people from the outside that the Government has to step in a force these people to do basic things (Shine, 2005).

Then Democrats Senator Aden Ridgeway said that dealing solely with behavioural issues does nothing to counter high unemployment or poverty:

In this system the Government gives with one hand and slaps with the other... [it has the] potential to turn into blackmail with the Government withholding essential resources until communities fall into line' (Ridgeway, 2004 cited in Coultan et al, 2004).

The Medical Joumal of Australia published an article from a group of Indigenous health practitioners, lawyers and politicians that described SRAs having 'overtones of paternalism', and questioned the notion of 'choice' offered to communities such as Mulan in receiving the discretionary government funding offered under SRAs (Collard et al, 2005: 502).

\section{Issues raised by the SRA framework}

\section{Mutual obligation and reciprocity}

Mutual obligation is a key Howard Government policy platform and is predicted to become the Government's most significant social policy legacy (Braithwaite et al, 2002: 225). The popular narratives that support mutual obligation (Harris, 2000: 280) - for example, that people should give something back in return for drawing on society's resources - have a rhetorical quality to them that resonates with a significant majority of Australians (Saulwick Age Poll, 2004).

In addition to popular support, there has been backing for murual obligation from some Indigenous leaders. Indeed, some have likened the government's mutual obligation approach to Indigenous concepts of 'reciprocity'. Patrick Dodson, a widely respected Aboriginal leader, has stated that:

The mutual obligation stuff has a lot of resonance within Aboriginal culrure and within Aboriginal notions of kinship. This concept has a grounding within our culture and society. It is nor just a Western concept and this is how we need to see it (Dodson, 2004, cited in Kelly 2004).

Noel Pearson, an Aboriginal leader from Cape York, sees that the introduction of welfare payments without a requirement to give anything back in return has led to 
an undermining of Aboriginal notions of reciprocity and in turn, powerlessness and dysfunction (Pearson, 2000). A chorus of other supporters - from Labor leaders (Swan, 1999; Tanner, 1999) to prominent new paternalist and contemporary communitarian theoreticians (Yeatman, 1999) - have contributed to mutual or reciprocal obligation gaining motherhood status in the Australian social policy debate (Kinnear, 2002: 249). Further, Indigenous communities are arguably realising real financial benefits from SRAs, to which they may otherwise not have had access, and communities certainly have a degree of flexibility in relation to what they sign up for under SRAs. So what is the problem with the version of mutual obligation underpinning SRAs?

As far as received wisdom goes, mutual obligation is highly contestable from moral and political viewpoints (Kinnear, 2002; Macintyre, 1998; Moss, 2000). Its detractors may have lost the last great mutual obligation debate, concerning work for the dole and other mutual obligation options under the Government's Australians Working Together reforms of 2002, but their concerns are particularly prescient in relation to the current debate on SRAs. Why should some of Australia's most disadvantaged citizens, already low on resources, be targeted and forced to perform certain duties in return for what the state should arguably provide for them anyway? Does building a basketball court for a community really generate an obligation? Mutual obligation brings together two parties to a contract - Indigenous communities and the state - but is it a fair contract between equal parties and is the exchange really reciprocal, as mutual obligation would imply?

In this paper we contend that there is a substantive power imbalance between the parties to SRAs and that there is very little that is reasonable about the exchanging of community infrastructure like petrol bowsers and sporting facilities for acquiescing to mainstream Australian social norms in relation to, for example, hygiene. Even Marshall observed that 'the right to receive implies an obligation to give' (cited in Macintyre, 1999: 115); however, as members of the broader community that has already made a contribution to the state, Indigenous communities have a right to receive basic support without obligation.

Underlying mutual obligation and the active welfare agenda more broadly are a number of problematic assumptions and normative shifts. There is a concern that the community at large will unwittingly read into mutual obligation's simplistic rhetoric the very concrete assumptions of new paternalism (Braithwaite et al, 2002: 226). For example, that in relation to some groups in the community, the state is a better judge of what people need than the people themselves. According to Lawrence Mead, the influential US new paternalist (1997: 2): 'These measures assume the people concerned need assistance but they also need direction if they are to live constructively.'

When applied to Indigenous affairs, this kind of view rests on the questionable propositions that self-determination did not work, and that its failure was the fault of Indigenous communities; therefore a completely different, more accountable, contractarian policy platform is a better answer. Just as 'passive welfare' is said not to have worked, having supposedly led to learned helplessness and dependence, active welfare and mutual obligation, it is said, will create self-reliant, self-governing communities and good citizens. These hollow catchphrases mask more complex underlying truths. As Judith Bessant observed of the unemployed (2000: 28), blaming them for their predicament shows a lack of understanding about the real causes of 
disadvantage, at best; at worst, it is indicative of a political strategy designed to divert attention away from the ineffectiveness of current policy and programs. And as Aboriginal leaders such as Professor Larissa Behrendt (2004) have stated regarding the application of mutual obligation to Indigenous policy:

This means that the Federal Government is attempting to reward those who meet standards of behaviour that the Government sets for them and punish those who do not.

Regarding the likening of 'mutual obligation' to Aboriginal notions of reciprocity, Behrendt cautions that such claims can too easily be taken out of context to support a governmental agenda and states that such an approach is 'misnamed as "mutual" and has no home in the values of Aboriginal culture - traditional, contemporary or romanticised' (Behrendt, 2004).

A problem with mutual obligation, as a reciprocal relationship, is that inherent in it is a shift in the parties to the relationship, from the state and the community or citizenry at large to the state and specific groups within society. Instead of the state being responsible to the community for supporting its most vulnerable, building capacity and promoting social cohesion, as has historically been the case (McClelland, 2002), it targets individuals or groups, such as income support recipients and Indigenous communities, for specific agreements. This potentially undermines important principles such as citizens' equal status and worth and fosters divisive distinctions between different groups in the community. Mutual obligation may actually compromise the Government's capacity to meet the responsibilities mentioned above. For example, under mutual obligation, the Government may use a vulnerable group's inability to meet its side of an agreement as a rationale for denying, withholding or reducing benefits or limiting choice (McClelland, 2002).

While there may be a creditable focus on individual and community capacity building under murual obligation, as it was interpreted in the McClure Report for example, there may also be a punitive orientation on the other (Braithwaite et al, 2002: 232). As yet there is no evidence of the state or its agencies forcing Indigenous communities to uphold their end of SRAs, nor punishing them for not doing so. As Rowse has pointed out, there are a number of diverse and competing models of mutual obligation already existing in Australian public policy, including the Indigenous-specific Community Development Employment Projects (CDEP) and 'work for the dole' schemes (Rowse, 2002), and the lessons from other models may not be directly comparable to SRAs. However, the Government has been forthright about SRAs falling within a policy continuum of mutual obligation, and it is reasonable to presume some consistency in approach. If the version of mutual obligation applied in Australians Working Together is indicative of the Government's intentions, SRAs will be compelling and failure to perform will attract penalties. If Work for the Dole participants fail to satisfy their participation agreements, they may be breached and have a breach penalty imposed on their payments. What will the consequences be of communities failing to meet their SRA obligations? Will the bowsers be shut off and community halls closed down? Will the nutrition and skills development courses be stopped? And what of the implications of compulsion and penalties? 
Reflecting on the impact of mutual obligation and compulsion on volunteerism (under certain circumstances income support recipients may choose to 'volunteer' to satisfy murual obligation or activity test requirements), Warburton and Smith (2003: 784) demonstrated that compulsion may reduce young people's inclination to volunteer in the future and thwart the development of pro-social behaviours and active citizenship. Compelling Indigenous communities to perform against SRAs could, ironically given the espoused rationale for them, compromise Indigenous communities' attitudes towards Government and society.

\section{Transparency, accountability, consistency}

Copies of the 121 agreements signed between governments and 86 Indigenous communities or groups have not been made publicly available. The Australian Government's Indigenous Portal contains general information about the community in which the SRA has been signed, the relevant government departments which are a signatory to the SRA, figures of government funds committed and general summaries of the focus and intended outcomes of the agreements (OIPC, 2006). However the website does not include detail of the specific objectives; performance indicators and benchmarks; any existing baseline data or community identified priorities; or dispute resolution, monitoring and evaluation mechanisms. Despite repeated requests from Tom Calma, the Aboriginal and Torres Strait Islander Social Justice Commissioner, and others, there has been little opportunity to scrutinise the detail of the SRAs that Indigenous communities are signing up to, nor to compare their terms or proportionality.

It is difficult to ascertain from information on the public record exactly how much funding is being spent on the government administration of SRAs, and whether it actually exceeds the amount reaching communities. Consultations conducted by the Centre for Aboriginal Economic Policy Research noted one example involving an estimated five days work to negotiate an SRA worth under $\$ 10,000$ (Hunt \& Smith, 2006: 48). There is anecdotal evidence that communities have been told that they should not give out information or data because under the terms of the SRA it is the property of the Commonwealth Government (Scott, 2005 cited in Graham, 2005). Professor Geoff Scott, former Deputy CEO of ATSIC, has pointed out the irony of this deliberate avoidance of public scrutiny of SRAs, given the 'rabid and detailed' levels of public accountability required of ATSIC when it existed (Scott, 2005 cited in Graham, 2005). Other commentators have suggested the portrayal of SRAs as the 'centrepiece' of Government policy is connected to this lack of transparency; that they represent a convenient 'media drip-feed' of positive examples of the Government addressing 'real' needs of communities without distracting information on the status and lack of progress on addressing problems on a national scale (Cooper, 2005: 8).

From what information is available, the SRAs signed to date vary significantly in terms of focus, commitments and funding. According to the Government's website, there has been only one SRA signed each in the ACT, Tasmania and Victoria under the COAG trials. There have been 30 signed in Western Australia, 27 in NSW, 24 in the Northern Territory, 11 in Queensland and seven in South Australia. The amount of funding committed by the Australian Government varies from $\$ 3,000$ for 'Activities for Young People' in Ringers Soak, Western Australia, to $\$ 2$ million to the Murdi Paaki Regional 
Assembly in New South Wales for 'Improving Living Conditions' (OIPC, 2006). The great majority of SRAs have been signed in remote Indigenous communities, and in the regions where well-resourced relationships and processes between Indigenous representative structures and governments under the COAG trials already existed. As the editor of the National Indigenous Times (NIT) has pointed out, the amount of money different communities receive under SRAs:

-.seems to bear no resemblance to the size of the problem or the outcome sought. Rather, it seems to depend on a combination of factors including the negotiating skills of the community; the negotiating skills of the bureaucrat directly involved in the agreement; and the government department which signs the agreement (Graham, 2005).

Funding does not appear to have been allocated on the basis of greatest or most urgent need, but by more arbitrarily prioritising those communities with well-developed social infrastructure or established relationships in working with government departments. Those communities with the greatest capacity to negotiate, and with proposals and processes that most appropriately suit the government's framework for developing SRAs, are more likely to receive funding.

There is little consistency between agreements, even those in communities in similar circumstances seeking to address similar problems. For example, the Government has variously committed $\$ 15,000$ for 'Structured activities for young people' in Balgo, Western Australia; $\$ 100,000$ for 'Sport and recreational activities for young people' in Western Australia'; and \$114,000 for a new scout troop in Yalata, South Australia. The National Indigenous Times has also reported that while the NSW community of Bourke, with an Aboriginal population approaching 4,000 people, will receive $\$ 47,000$ to 'Make the town safer', the Northern Territory community of Tennant Creek, with an Aboriginal population of around 1,250, will receive $\$ 363,000$ to create 'a safer community', despite the fact that the annual number of assaults in Bourke in 2004 was almost eight times the NSW average, while Tennant Creek's assault rate sits at around the Territory average (Graham, 2005).

The detail of the agreements may raise further concerns in relation to the broader objectives and future ramifications of SRAs. The Murdi Paaki Regional Assembly, formerly an ATSIC Regional Council and party to earlier SRA signed under the COAG trials, has distributed a copy of one of its more controversial agreements. Under this SRA, listed on the Government's website as 'Improving Living Conditions', the Commonwealth Government committed to providing \$2 million to install air conditioning units in 200 houses in communities in western NSW. The NSW Government committed to administer the funds and give technical support. In return, the funding is dependant on individual communities then developing their own SRAs, and each community having members who ensure the project is working by developing technical knowledge and monitoring the units. The Murdi Paaki Regional Housing Corporation will also employ a co-ordinator to oversee the program. Of significant concern are the stated longer-term outcomes of the SRA as 'improved living conditions; increase in school attendance; and decrease in the incidence of family violence'. These outcomes seem extraordinarily disproportionate given the Government's commitment of funding 200 air conditioners. What the consequences may be for those communities 
if the rates of family violence do not drop, or school attendance does not increase, is unclear.

It has become apparent that despite the rhetoric surrounding 'mutual obligation' and 'shared responsibility', the Government is not fulfilling its commitments under SRAs in reasonable timeframes and that the agreements are not having the effects that the Government claimed they would. In the case of Murdi Paaki, despite the community meeting its obligations under the SRA set out above, two and a half years later no air conditioners had been installed (Graham, 2005b: 8). The Chair of the Murdi Paaki Regional Assembly, Sam Jeffries, has been quoted as saying that members of the Assembly were having to spend all their time negotiating separate individual SRAs for funding from governments:

The Shared Responsibility Agreements have become the centrepiece, rather than actually doing something about the issues (Jeffries, 2005 cited in Graham, 2005b).

The community of Mulan did not receive their petrol bowser until January 2006, over 12 months after their SRA negotiations became public (Karvelas, 2006a). During that time, rates of trachoma once again increased in the community to 58 percent. The community was reportedly devastated at the increase after it had made efforts to fulfil its side of the SRA and continue the face-washing program and hygiene measures. Despite evidence from health experts that face-washing programs need to be integrated with screening and treatment programs and environmental health programs to have maximum impact on trachoma rates (Kowal, 2006: 292), then Minister Vanstone responded to the increase by stating:

I suspect there were some people waiting for the bowser to arrive... I can see some people thinking 'we agreed to do this when we got the bowser' (Vanstone, 2006 cited in Karvelas, 2006a).

Such examples highlight the limitations of the SRA framework, and the approach of murual obligation more generally. Issues of systemic disadvantage cannor be adequately addressed by simplistic, targeted agreements between governments and groups with significantly less power and agency.

There is little provision for or demonstrated commitment to independent monitoring or evaluation of SRAs on the part of governments, which leaves communities with little recourse. As Aboriginal leader Mick Dodson has stated:

How do we know if the agreements are working if there's no evaluation built into them? There is enormous political pressure on bureaucrats to boost the numbers of shared responsibility agreements because they look good politically (Dodson, 2005 cited in Khadem, 2005).

SRAs are not connected to broader planning processes, or based on research or data collection that may identify the key areas of need and best strategies for targeting government funding. There is no clear process set out in the event that any party to the SRA does not live up to its commitments. Without a clear and resourced process for independent monitoring or evaluation of SRAs, it is difficult to ensure accountability and 
responsibility. These structural flaws in the approach to SRAs disproportionately impact on Indigenous communities.

Imbalance of power between Indigenous communities and governments

SRAs appear to represent an extreme case of an imbalance of power between two parties to a negoriated agreement. Irrespective of the intentions of the parties to SRAs, structural biases favour the state and its agencies over Indigenous communities. This power imbalance manifests in relations between the parties that are more independent than interdependent - negotiations focus on narrow agendas rather than joint problem solving - and outcomes are more distributive than integrative, with little evidence of real give and take; claiming rather than creating value as Harvard negotiation professor James Sebenius refers to it (2001).

In SRA negotiations, Indigenous negotiators generally negotiate for their own communities. Because the negotiated outcomes impact upon them and their communities directly, they are more emotionally bound to the negoriation. Agents of government departments, on the other hand, can negotiate relatively dispassionately because of their distance from the negotiated outcomes; they are representing others (the government and the broader community). Their detachment allows them to be more calm and considered and they can use tactics not open to their counterparts, such as stalling a negotiation to give themselves time for reflection and strategy development: 'You've made your position clear. I can't commit on that point now. I'll need to consult with my boss first.'

Indigenous representative structures, such as ATSIC, have been broken down and the Government has stated that it wishes to work directly with Indigenous 'families, communities and clans'. According to the Social Justice Commissioner, while there have recently been attempts made to improve the way governments engage with Indigenous communities:

...significant gaps remain in Indigenous representation at local, regional and national levels. The absence of a framework for Indigenous representation at all levels of decision-making undermines and contradicts the aims of the new arrangements, and restricts the ability of Indigenous people to participate in decision-making processes (Calma, 2006b).

Faced with a fragmented other party, government departments can more easily 'divide and conquer', separately negotiating SRAs with individual groups or communities, taking different positions and focusing on different issues each time. In essence, this parallels attempts to break down worker representation in industrial relations-and the outcome is the same: less power in the hands of the fractured party.

As the government will not make the detail of past SRAs available and representative structures are no longer resourced or networked to share relevant information and learnings from previous SRA negotiations, Indigenous communities are at a significant disadvantage when negotiating with a bureaucracy that has a more transparent view across multiple agreements. While this presumes that government agencies effectively monitor and share information, the fact remains that government representatives may benefit from an asymmetry of information because - as members of the same 
organisation - they can potentially draw on completed SRAs and access privileged information about previous SRA negotiations. The power that comes from superior access to information is not the only power source that favours government negotiators; they are also in a position to withhold funding and services and are likely to have access to more resources than their Indigenous community counterparts. With the moral authority of representative government behind them, along with the powerful personal endorsements of the Prime Minister and other prominent ministers and some Indigenous community leaders, government negotiators are in a very strong position as they take their seats at the negotiating table. Indigenous negotiators' relative power is further constrained by their lack of alternatives to a successfully negotiated outcome: if they cannot strike an SRA with government, they can reasonably expect that it will be difficult to find other sources of funding to meet their needs. Indigenous communities do not have what negotiators call a BATNA, a best alternative to a negotiated agreement (Fisher and Ury 1981). The Government, on the other hand, is negotiating several agreements at any time, so if an SRA deal is not to their satisfaction, they can walk away safe in the knowledge that there will be other SRAs to add to those that have already been signed.

There are governance and cultural issues that put Indigenous community negotiators at a disadvantage too. For example, in negotiating SRAs, government departments, typically specific agencies, negotiate with Indigenous communities, the governance arrangements and parameters of which may be less well defined. Accordingly, consultation and representation can be more problematic for the Indigenous side. Factors such as less hierarchical community structures, different ways of dealing with conflict and different preferences in relation to action and reflection may compound the multifarious challenges facing Indigenous negotiators.

\section{Discretionary benefits or human rights?}

A major source of criticism of SRAs has been their porential to breach the human rights of Aboriginal and Torres Strait Islander people. The Government has, increasingly in response to criticism, stressed that SRAs do not affect ordinary citizenship entitlements and that funding allocated under SRAs is 'discretionary' and not for essential infrastructure or services. However, what is considered 'discretionary' and what is a general citizenship right remains contested. Requiring Indigenous communities to commit to behavioural change and other actions in order to receive funding for services that other Australians take for granted certainly raises the potential of racial discrimination. This is particularly the case when Indigenous people are the most disadvantaged and marginalised group in Australia against indicators relating to health, housing, employment and education, and when there is evidence that governments already underspend significantly on services to Indigenous people (Access Economics, 2004, Commonwealth Grants Commission, 2001). Additionally, Australia has international human rights obligations relating to the rights of Indigenous people affected by agreements to free, prior and informed consent. The SRA negotiation process could arguably breach those human rights due to, for example, representational inadequacies and a lack of options in relation to how Indigenous communities access funding. 
From the scant information that is available, it would appear that under some SRAs, funding for essential infrastructure or services is being provided. In Coonana, Western Australia, the community of 90-120 people has entered into an SRA to improve their water supply. The community relies on dam water that is contaminated by feral horses, cattle and camels which is adversely affecting their health. Under the SRA, the Government will provide $\$ 40,500$ to fund trap yards, troughs and fencing around the dams to control the feral animals. In return, the community will monitor the stock, build the traps yards and fencing, and maintain the dams. They will also establish a work team to supply labour to local pastoralists. An adequate and clean water supply should by any measure be a citizenship entitlement in a country such as Australia.

In Enngonia, NSW, there is an SRA focused on encouraging young people who do not currently attend the closest high school in Bourke, $100 \mathrm{~km}$ away, to participate in a distance education program. The Commonwealth Government will provide $\$ 20,000$ to cover rent and costs such as electricity, as well as an Aboriginal teacher's aide for the project and bus trips for joint school days with Bourke High School. The NSW Government will provide a casual teacher based in Enngonia for high school students, and will also provide desks, sporting and electronic equipment, and monitor test results. When the community of Wadeye adopted a 'no school, no pool' policy, it was widely promoted by the Federal and Northern Territory Governments as a successful example of mutual obligation working in practice in Indigenous communities. However, what was less reported was the fact that when hundreds of children did enrol in school, there was not enough room or facilities to accommodate them (McLaughlin, 2005). As Robbins (2005) has observed, if such services are now conditional to Indigenous communities, then it would suggest that there is inequality in the practical meaning of citizenship in Australia.

Governments promote SRAs as offering Indigenous communities more choice and flexibility in identifying local priorities and accessing government funding. However, the mantra of choice and flexibility rings hollow when SRAs provide the only means of Indigenous communities accessing funds for essential infrastructure or services. Many of the contributions to SRAs by the Government come in the form of CDEP places, and both funding for the positions and the labour of the CDEP participants is regularly included in SRAs. Given that these positions are subject to a range of existing and changing Government conditions and requirements, this raises further questions about the choice and flexibility of communities in entering into such agreements. The Aboriginal and Torres Strait Islander Social Justice Commissioner, has also made the point that an SRA may still breach human rights even if it is not providing essential services, if it is provided in a manner that is discriminatory or that makes addressing existing inequalities contingent upon the completion of mutual obligation requirements (Calma, 2006a: 41).

\section{The responsibility for change lies with the community}

The SRA framework implies that Indigenous communities are not willing to initiate programs and measures to help themselves without some form of contractual obligation. It ignores the complex causes of disadvantage in Indigenous communities, and the role that adequate government funding for Indigenous driven initiatives can play in addressing many problems in communities. It also ignores all the evidence that suggests that genuine support for Indigenous decision making and control over 
policy, programs and services is key to overcoming Indigenous disadvantage. In many areas, individuals and organisations are instigating programs and strategies to address Indigenous disadvantage with little support or recognition from governments. Indeed, Aden Ridgeway and others have pointed out that the Government has been conveniently rebadging such long term, grassroots work in communities as their own and then calling SRAs an instant policy success (Coultan et al, 2004, Shine, 2005). The implication that it is only communities who need to lift their game is also disingenuous given the recent loss of skilled and experienced personnel in the public sector, particularly Indigenous people, who can work effectively with Indigenous communities. Such expertise is crucial to making such a policy framework effective, and yet has been undermined in the Government's new arrangements (Australian Public Service Commission, 2005). As Reconciliation Australia pointed out in their submission to the Senate Select Committee into the Administration of Indigenous Affairs:

Just as it is dangerous to make assumptions about lack of capacity within Indigenous communities, it is potentially even more dangerous to assume capacity within government agencies to deliver this level of change. It appears that government policy is well ahead of government agencies' capacity to manage implementation or deal with its consequences (Reconciliation Australia, 2005: 5).

Funding for SRAs must be provided to communities through incorporated organisations, and Indigenous representatives must have the authority and mandate to sign up to SRAs, and to ensure accountability and effectiveness. Indigenous representative structures are crucial to enabling governments to work effectively at the local level. Despite this reality, former Indigenous Affairs Minister Vanstone has stated that:

The days are over of other people getting jobs telling the Australian Government what communities want... Those jobs are no longer available, we will be speaking directly with the community. It's a fundamentally different way of working (Vanstone, 2005 cited in Maiden, 2005).

Ironically, the Government appears to be comfortable with an organisational interface of its own, expending considerable funds on consultants to assist in administering the SRA process (Graham, 2005).

\section{The Way Forward}

As we have set out in this article, there are many Indigenous communities in dire need who are not benefiting from funding allocated by the Government for SRAs. Most Indigenous people live in urban areas, and the Government's focus with SRAs is disproportionately on remote and distinct regional communities. There are other communities who are committing to disproportionate and unrealistic measures under SRAs. There is anecdotal evidence of SRAs privileging individuals and groups within communities who go along with the agreements, raising possible inter and intra-community distribution issues. Some representatives may be signing up to SRAs without sufficient mandate or capacity to influence others in their communities to fulfil the commitments made. These developments may have negative ramifications for communities in the future, including their capacity to secure other funding from governments. 
Despite such criticisms, in a funding environment where Indigenous communities are starved of services, infrastructure and expertise (Cooper, 2005: 7), there is arguably a need for pragmatism in supporting communities to get the best outcomes from the SRA framework. While the debate regarding their moral force or efficacy continues, SRAs are in the ascendency. New Minister for Indigenous Affairs, Mal Brough, has indicated that he is committed to improving outcomes under SRAs, and will reportedly work with the Government-appointed National Indigenous Council to ensure the agreements are being taken seriously (Brough, 2006 cited in Karvelas, 2006b).

For communities that are resourceful, with effective representative structures and the capacity to negotiate effectively with governments, SRAs can be a means to access funding for much-needed infrastructure and services. Those indigenous communities that do have the opportunity and inclination to negotiate SRAs need to build capacity to increase their negotiating power and maximise the outcomes they can achieve from SRAs. They can employ various strategies to do so, including learning from other communities' experiences negotiating SRAs; conducting negotiation training; using the media to advance their negotiating positions; or getting agents (professional negotiators) to act on their behalf, or at least to provide counsel and support. If SRAs are to be part of the social policy landscape for the foreseeable future, and there is a genuine desire to maximise outcomes for both parties, a more strategic approach is called for. Such an approach could involve creating a national representative Indigenous body with an 'institutional negotiation capability' (Ertel, 1999: 68) that can work with the government to agree SRA principles and practices, and encourage the Government to take a fairer approach to SRAs. That body could also play a crucial monitoring role to ensure consistency and accountability. Working together at the institutional level, governments and the Indigenous representative body could create a social contract and agree on the 'spirit' of SRAs (Fortgang et al, 2003: 67), rising above individual agreements to create a better mutual understanding, and surface and share value-creating ideas that 'expand the fixed pie' (Bazerman, 1993: 203).

SRAs are not legally binding and the progress review and dispute settling arrangements written into them are frequently vague; as a result, communities lack the power to ensure that governments deliver on their commitments. Consideration could be given to whether SRAs can be underpinned by legally binding funding contracts. Communities need something more than a statement of goodwill from governments: some form of greater accountability, either via funding contracts or other means, is required so that communities get what they negotiate for on a timely basis.

\section{Conclusion}

The Howard Government has championed SRAs as a key plank in its new approach to the administration of Indigenous affairs, and maligned past policies as having reinforced the influence of ineffective institutions and fostered an environment of welfare dependency and passivity. In their current guise at least, SRAs seem an unlikely panacea for disadvantage: their rationale seems simplistic and confused, their application ill conceived and haphazard, and their consequences uncertain. If SRAs are to be fairer and more effective, greater attention needs to be paid to how they are initiated and framed, how they are resourced, who signs up to them, and how they are negotiated, 
implemented and monitored. There remains a chronic level of under-funding in Indigenous health, housing and education. Making resources which are desperately needed in Indigenous communities conditional on particular changes - the measurement and feasibility of which remain unclear - raises questions of paternalism, coercion and equality of citizenship for Indigenous people.

\section{References}

AAP (2004) 'Howard "unhappy" with Aboriginal health', The Age, December 10, available at http://www.theage.com.au/news/National/Howard-unhappy-with-Ab original-health/2004/12/10/1102625508797.html

Access Economics (2004) Indigenous health workforce needs: A report for the Australian Medical Association. Sydney: Access Economics.

Australian Public Service Commission (2005) State of the Service Report 2004-2005, Canberra: Commonwealth Government of Australia.

Bazerman, M.H. (1986) 'Why negotiations go wrong', Psychology Today, June, reprinted in R. J. Lewicki, J. A. Litterer, D.M. Saunders \& J. W. Minton (eds) Negotiation, 2nd Ed, 1993, Illinois: Irwin, 203-208.

Behrendt, L. (2004) 'Nothing murual about denying Aborigines a voice', The Sydney Morning Herald, 8 December, available ar http://www.smh.com.au/news/ Opinion/Nothing-mutual-about-denying-Aborigines-a-voice/2004/12/07/1102182 295283.html

Bessant, J. (2000) 'Civil conscription or reciprocal obligation: the ethics of 'work-for-the-dole', Australian Journal of Social Issues, 35 (1), 15-33.

Braithwaire, V., Gatens, M. \& Mitchell, D. (2002) 'If mutual obligation is the answer, what is the question?', Australian Journal of Social Issues, 37 (3), 225-245.

Calma, T. (2006a) Social Justice Report 2005, Sydney: Human Rights and Equal Opportunity Commission.

Calma, T. (2006b) 'Social Justice Commissioner says results mixed in the implementation of new arrangements for Indigenous affairs', Media Release, 16 February, available at http://www.humanrights.gov.au/social_justice/sjreport05/SJR2005_media1. html

Carr, K. (2004) cited in Hall, E. (2004) 'Government makes 'shared responsibility' deal with WA Indigenous community', The World Today, ABC Radio, 9 December, available at http://www.abc.net.au/worldtoday/content/2004/s1261373.htm

COAG, (2002) 'Reconciliation', Council of Australian Governments Communiqué, Canberra, 5 April.

Collard, K., D’Antoine, H., Eggington, D., Henry, B., Martin, C. \& Mooney, G. (2005) 'Mutual obligation in Indigenous health: can shared responsibility agreements be truly mutual?', Medical Journal of Australia, 182 (10) 16 May: 502-504.

Commonwealth Grants Commission (2001) Report on Indigenous Funding, Canberra: Commonwealth Government of Australia.

Cooper, D. (2005) 'Shared Responsibility Agreements: Whitewashing Indigenous Service Delivery'. Indigenous Law Bulletin, 6 (15), November: 6-9. 
Coultan, M. \& Metherell, M. (2004) 'A new deal for indigenous Australia', The Sydney Morning Herald, December 11, available at http://www.smh.com.au/articles/200 4/12/10/1102625532962.html

Dodson, P. \& Pearson, N. (2004) 'The Dangers of Mutual Obligation', The Age, 15 December, available at http://www.theage.com.au/news/Opinion/The-dangers-of -mutual-obligation/2004/12/14/1102787075763.html

Donald, P. (2004) 'Mulan deal a return to native welfare days: Dodson', ABC Radio PM, 9 December, available at http://www.abc.net.au/pm/content/2004/s1261745.htm

Doonday, B. Lulu, F., Whisputt, M., Johns, A. \& all the elders, council and families of the Mulan Aboriginal community (2005) 'Striving for equality in every way', The Age, 14 December.

Ertel, D. (1999) 'Turning negotiation into a corporate capability', Harvard Business Review, May-June, 55-70.

Fisher, R. \& Ury, W. L. (1981) Getting to yes: negotiating agreement without giving in, Massachuserts: Houghton Mifflin.

Fortgang, R. S., Lax, D. A. \& Sebenius, J. K. (2003) 'Negotiating the spirit of the deal', Harvard Business Review, February, 66-75.

Graham, C. (2005a) 'The dollars and sense of Shared Responsibility Agreements just don't add up', National Indigenous Times 88, 1 September.

Graham, C. (2005b) '"Murual" MIA in govt's MO', National Indigenous Times 92, 10 November.

Hall, E. (2004) 'Government makes 'shared responsibility' deal with WA Indigenous community', The World Today, ABC Radio, 9 December, available at http://www. abc.net.au/worldtoday/content/2004/s1261373.htm

Harris, P. (2000) 'Participation and the new welfare', Australian Journal of Social Issues, 35 (4), 279-300.

Howard, J., Prime Minister (2004a) 'Joint Press Conference with Senator Amanda Vanstone, Parliament House', Canberra, 15 April.

Howard, J., Prime Minister (2004b) cited in 'Howard "unhappy" with Aboriginal health', The Age, December 10, available at http://www.theage.com.au/news/National/ Howard-unhappy-with-Aboriginal-health/2004/12/10/1102625508797.html

Hunt, J. \& Smith, D.E. (2006) Building Indigenous Community Governance in Australia: Preliminary Research Findings, Working Paper No. 31, May, Australian National University: Centre for Aboriginal Economic Policy Research.

Karvelas, P. (2006a) 'Face-washing deal under the pump', The Australian, 20 January.

Karvelas, P. (2006b) 'Aboriginal deals to face overhaul', The Australian, 17 June.

Kelly, P. (2004) 'Black leaders offer new accord', The Australian, 4 December.

Khadem, N. (2005) 'Aborigines fear basic rights loss', The Age, 26 September, available at http://www.theage.com.au/news/national/aborigines-fear-basic-rights-loss/200 $5 / 09 / 25 / 1127586746550$. html?from=moreStories 
Kinnear, P. (2001) 'Mutual obligation: a reasonable policy?'. In T. Eardley \& B. Bradbury (eds) 'Competing visions', Proceedings of the National Social Policy Conference, Sydney, July, 248-262.

Kowal, E. (2006) 'Murual obligation and Indigenous health: thinking through incentives and obligations', Medical Joumal of Australia 184 (6), 20 March: 292-293.

Macintyre, C. (1999) 'From entitlement to obligation in the Australian Welfare State', Australian Journal of Social Issues, 34 (2), 103-118.

Maiden, S. (2005) 'New deals "will end the welfare mafia"', The Australian, 28 May.

Martin, C. (2004) cited in 'MP says Mulan needs services, not "shared responsibility", The World Today, ABC Radio, 9 December, available at http://www.abc.net.au/ worldtoday/content/2004/s1261467.htm

McClelland, A. (2002) 'Mutual obligation and the welfare responsibilities of government', Australian Journal of Social Issues, 37 (3), 209-224.

McLaughlin, M. (2005) 'Questions raised over Wadeye program', 7:30 Report, ABC TV, 28 April, available at http://www.abc.net.au/7.30/content/2005/s1355870.htm

Mead, L. (1997) 'The rise of paternalism' in L. Mead (ed) The new paternalism: supervisory approaches to poverty, Washington, DC: Brookings Institution Press, $1-38$.

Moss, J. (2000) 'The ethics and politics of mutual obligation', Australian Joumal of Social Issues, 35 (4), 1-14.

Newspoll Opinion Polls (2004) Question about whether respondents were generally in favour of Shared Responsibility Agreements, 28 December, available at http:// www.newspoll.com.au/image_uploads/cgi-lib.31400.11205_shared_responsibility_ agreements.pdf

Office of Indigenous Policy Co-ordination (2006) What are Shared Responsibility Agreements?, available athttp://www.indigenous.gov.au/sra/kit/what_are.pdf

OIPC (2006) SRAs and RPAs website, Office of Indigenous Policy Co-ordination Indigenous Portal, available at http://www.indigenous.gov.au/sra.html

Pearson, N. (2000) Our right to take responsibility, Cairns: Noel Pearson and Associates.

Peatling, S. (2005) 'Let's make a deal: Vanstone lauds quiet revolution', Sydney Morning Herald, 28 May, available at http://www.smh.com.au/news/National/Lets-make-adeal-Vanstone-lauds-quiet-revolution/2005/05/27/1117129901109.html

Pennells, S. (2004) 'Rules unfair, say proud Mulan people', The Age, 10 December, available at http://www.theage.com.au/news/National/Rules-unfair-say-proud-Mu lan-people/2004/12/09/1102182430767.html

Reconciliation Australia (2005) Submission 225, Senate Select Committee on the Administration of Affairs, March.

Robbins, J. (2005) 'Life after ATSIC: Indigenous Citizenship in an era of mutual obligation', paper presented at te ASPA Conference, University of Otago, Dunedin NZ, September.

Rowse, T. (2002) 'McClure's "mutual obligation" and Pearson's "reciprocity" - can they be reconciled?', Australian Joumal of Social Issues, 37 (3), 263-276. 
Saulwick Age Poll (2004) 'What Australians think', The Age, 6 September.

Sebenius, J. K. (2001) 'Six Habits of merely effective negotiators', Harvard Business Review, April, 87-95.

Shergold, P. (2004) 'Connecting Government: Whole-of-Government Responses to Australia's Priority Challenges', Report No. 4, 20 April.

Shine, K. (2005) 'Black responsibility deals 'no miracle',' The Australian, 16 May.

Swan, W. (1999) 'Two-way street to end poverty traps', Sydney Morning Herald, 6 May.

Tanner, L. (1999) Open Australia, Annandale: Pluto Press.

Warburton, J. \& Smith, J. (2003) 'Out of the generosity of your heart: are we creating active citizens through compulsory volunteering programs for young people in Australia?', Social Policy o Administration, 37 (7), 772-786.

Yeatman, A. (1999) 'Mutual obligation: what kind of contract is this?', in S. Shaver \& P. Saunders (eds) Social Policy for the 21st Century: Justice and Responsibility, Proceedings of the National Social Policy Conference, Sydney, July, 255-268. 